\title{
KESADARAN DAN PENGATURAN BERPIKIR SISWA DALAM MENYELESAIKAN MASALAH PADA SOAL PISA
}

\author{
Pingki Dinda Harmilia ${ }^{1}$, Eric Dwi Putra ${ }^{2}$, Dwi Noviani Sulisawati ${ }^{3}$ \\ IKIP PGRI Jember ${ }^{1,2,3}$ \\ dwi.moshimoshi@gmail.com ${ }^{3}$
}

\begin{abstract}
ABSTRAK
Penelitian ini bertujuan untuk mendeskripsikan kesadaran dan pengaturan berpikir siswa dalam menyelesaikan masalah pada soal PISA. Penelitian ini berjenis penelitian kualitatif. Dipilih 2 siswa kelas XI SMA Nurul Islam Jember sebagai subjek penelitian, 1 siswa untuk kategori siswa yang memiliki nilai paling tinggi dan 1 siswa untuk kategori siswa yang memiliki nilai paling rendah. Data dikumpulkan melalui tes dan wawancara. Dilakukan analisis terhadap kesadaran penuh dan pengaturan berpikir siswa dalam menyelesaikan soal-soal permasalahan berjenis PISA pada mata pelajaran matematika. Komponen kesadaran dan pengaturan berpikir siswa dalam menyelesaikan masalah pada soal PISA yaitu attention, recall of knowledge, planning, monitoring dan evaluation. Berdasarkan hasil penelitian, diperoleh bahwa kesadaran dan pengaturan berpikir siswa berkemampuan tinggi dan siswa berkemampuan rendah berbeda serta bergerak secara tidak linear. Siswa berkemampuan tinggi dalam menyelesaikan masalah pada materi kecepatan yaitu melalui komponen attention, recall of knowledge, planning, planning, monitoring, evaluation, attention, attention, monitoring, recall of knowledge, planning, monitoring, recall of knowledge, planning, monitoring kemudian evaluation. Sedangkan kesadaran dan pengaturan berpikir siswa berkemampuan rendah dalam menyelesaikan masalah pada materi kecepatan yaitu melalui komponen attention, recall of knowledge, planning, planning, monitoring, evaluation, attention, attention, monitoring, recall of knowledge, planning, monitoring, recall of knowledge, planning, monitoring kemudian evaluation.
\end{abstract}

Kata kunci : kesadaran dan pengaturan berpikir, soal PISA

\begin{abstract}
This study aims to describe the awareness and thinking arrangements of students in solving problems on PISA questions. This research is a qualitative research. Two students of class XI SMA Nurul Islam Jember were chosen as research subjects, 1 student for the category of the student who had the highest score and 1 student for the category of the student who had the lowest score. Data were collected through tests and interviews. An analysis of the full awareness and management of students' thinking was carried out in solving PISA-type problems in mathematics. The components of students' awareness and thinking arrangements in solving problems on PISA questions are attention, recall of knowledge, planning, monitoring, and evaluation. Based on the results of the study, it was found that the awareness and thinking arrangements of highability students and low-ability students were different and moved non-linearly. Students with high abilities in solving problems in the material speed, namely through the components of attention, recall of knowledge, planning, planning, monitoring, evaluation, attention, attention, monitoring, recall of knowledge,
\end{abstract}


planning, monitoring, recall of knowledge, planning, monitoring and then evaluation. While the awareness and thinking arrangement of students with low abilities in solving problems in the material speed, namely through the components of attention, recall of knowledge, planning, planning, monitoring, evaluation, attention, attention, monitoring, recall of knowledge, planning, monitoring, recall of knowledge, planning, monitoring then evaluation.

Keywords : awareness and thinking regulation, PISA questions

\section{PENDAHULUAN}

Agar dapat menyelesaikan masalah yang terdapat pada soal PISA, tentunya siswa harus menghindari kesalahan-kesalahan saat mengerjakan soal terutama dalam pengambilan langkah-langkah pengerjaannya, agar siswa tidak sampai diremidi untuk mencapai nilai ketuntasan standar dari sekolah pada mata pelajaran matematika. Berdasarkan hasil wawancara dengan guru matematika di SMA Nurul Islam Jember, siswa akan diremidi secara berulang-ulang karena guru tidak mengetahui letak kesalahan dan kesulitan proses penyelesaian masalah pada soal yang dikerjakan, sedangkan ketika ditanya oleh guru mengenai paham atau tidaknya terhadap sebuah materi, siswa selalu menjawab paham namun hal tersebut tidak selaras dengan hasil belajar siswa. Masalah kesulitan siswa dapat diketahui berdasarkan jenis soal, seperti yang ada di SMA Nurul Islam Jember, melalui wawancara yang telah dilakukan kepada siswa banyak yang tidak mengetahui soal matematika berjenis PISA. Siswa tidak mengetahui "Apa itu soal PISA?" sehingga hal tersebut dapat berpengaruh kepada berkembangan pola pikir siswa.

Terdapat beberapa faktor yang menyebabkan Indonesia berada pada peringkat rendah dalam studi PISA, kurangnya berlatih dalam menyelesaikan soal bertipe PISA merupakan salah satu faktor penyebab Indonesia menduduki peringkat terendah studi PISA, hal ini mengakibatkan hasil perkembangan PISA di Indonesia tidak signifikan (Wardhani dan Rumiati, 2011)

PISA (Programme Internationale for Student Assesment) merupakan bentuk evaluasi kemampuan khusus siswa berusia 15 tahun dalam memahami pengetahuan yang telah diperolehnya (Shiel dalam Dhany, 2013). PISA sendiri merupakan proyek dari Organization for Economic Co-operation and Development (OECD) yang pertama kali diselenggarakan pada tahun 2000 untuk bidang membaca, matematika dan sains. Ide utama dari PISA adalah hasil dari sistem pendidikan harus diukur dengan kompetensi yang dimiliki oleh siswa dan konsep utamanya adalah literasi (Neubrand dalam Dhany, 2013).

PISA adalah tipe soal matematika untuk mengidentifikasi unsur-unsur, variabel, untuk memahami struktur dalam matematika pada konteks nyata. Selain itu, PISA juga dapat menyederhanakan masalah sehingga mudah dianalisis secara matematika menggunakan variabel, simbol, diagram, model matematika yang sesuai untuk menjelaskan permasalahan matematika kemudian diterjemahkan sesuai dengan bahasa, konsep dan fakta matematika.

Matematika dapat dijawab secara berbeda-beda tergantung pada bagaimana pertanyaan itu dijawab, dimana dijawabnya, siapa yang menjawabnya, dan apa sajakah yang dipandang termasuk dalam matematika melalui daya nalar (Suherman, 2001). Untuk membangun daya nalar yang kuat siswa harus memiliki kesadaran dan 
pengaruh berpikir yang baik. Kesadaran akan memahami soal, kesadaran akan memecahkan permasalahan dan kesadaran akan menyelesaikan soal. Menurut Brigham (1991) kesadaran merupakan keadaan yang dialami manusia ketika mengarahkan perhatiannya untuk memfokuskan pada isi diri sendiri atau derajat perhatian yang diarahkan untuk memusatkan perhatian pada aspek diri sendiri. Kesadaran berpikir mempunyai komponen attention, architecture, recall of knowledge, emotive, novelty, emergence, selectivy dan subyectivity.

Penelitian ini difokuskan pada komponen kesadaran attention dan recall of knowledge. Sebab komponen lainnya termasuk dalam proses fisiologi dan proses psikologis (Solso dalam Baidawi, 2017). Pada umumnya pengaturan berpikir dan pengaturan diri adalah dua hal yang memiliki kesamaan. Pengaturan diri berasal dari dua kata, yakni pengaturan (regulation) dan diri (self). Menurut Sunck (Sulisawati, 2013) pengaturan sendiri diartikan sebagai kemampuan untuk mengontrol. Sedangkan pengaturan berpikir mengacu kepada planning, monitoring dan evaluation. Berdasarkan pendapat Solso (2008) serta Schraw dan Moshman (1995) kesadaran dan pengaturan berpikir pada penelitian ini difokuskan kepada attention, recall information, planning, monitoring dan evaluation. Sebab attention merupakan pemusatan pikiran pada pemrosesan informasi yang diperoleh dari soal. Recall information merupakan aktivitas pemanggilan informasi yang sudah dimiliki. Planning merupakan pemilihan strategi dalam menyelesaikan masalah. Kemudian monitoring merupakan kegiatan bertanya pada dirinya sendiri apakah kinerjanya sudah benar atau belum, apa yang harus dikerjakan jika ada kesalahan dan kesesuaian strategi yang digunakan. Serta evaluation merupakan aktivitas asesmen mengenai hasil, masalah kesulitan, kemajuan, kemampuan atau pemahaman (Schraw dan Moshman dalam Baidawi, 2017).

Dalam menyelesaikan masalah tentu membutuhkan langkah-langkah yang tepat untuk menuntun dan mempermudah siswa menyelesaikan permasalahan pada soal dengan baik. Terdapat beberapa teori yang menyajikan beberapa langkah dalam menyelesaikan masalah. Salah satunya yaitu teori penyelesaian masalah dari Gick (dalam Widjajanti, 2009) diantaranya adalah: 1) Menyajikan masalah, termasuk memanggil kembali konteks pengetahuan yang sesuai, dan mengidentifikasi tujuan dan kondisi awal yang relevan dari masalah tersebut, 2) Mencari penyelesaian, termasuk memperhalus tujuan dan mengembangkan suatu rencana untuk bertindak guna mencapai tujuan, dan 3) Menerapkan penyelesaian, termasuk melaksanakan rencana dan menilai hasilnya.

Sehingga dalam kasus ini, dengan diketahui kesadaran dan pengaturan berpikir siswa berkemampuan tinggi dan siswa berkemampuan rendah dalam menyelesaikan masalah pada soal PISA, dapat diketahui letak langkah-langkah kesalahan siswa dalam menyelesaikan masalah pada soal PISA, melalui 3 langkah penyelesaian masalah dari Gick (dalam Widjajanti, 2009) yaitu menyajikan masalah, mencari penyelesaian, dan menerapkan penyelesaian yang dikolaborasikan dengan beberapa komponen kesadaran dan pengaturan berpikir siswa sesuai dengan teori dari Baidawi (2017) yaitu attention, recall information, planning, monitoring dan evaluation. Maka, dalam setiap langkah penyelesaian masalah menurut Gick (dalam Widjajanti, 2009) terdapat 5 komponen kesadaran dan pengaturan berpikir siswa menurut Baidawi (2017). Dengan begitu, dapat diketahui dan dideskripsikan bagaimana kesadaran dan pengaturan berpikir siswa dalam menyelesaikan masalah pada soal PISA. 
Beberapa penelitian yang telah dilakukan oleh sebagian orang menyatakan bahwa soal PISA memberikan dampak baik bagi siswa untuk berusaha memecahkan masalah. Menurut Zayyadi dan Sulfiah (2018) soal PISA dapat membantu siswa dalam memecahkan masalah, diantaranya yaitu: 1) Siswa dapat menyelesaikan soal rutin (soal yang biasa mereka terima), 2) Siswa dapat menafsirkan dan mengenali situasi dalam konteks yang memerlukan kesimpulan langsung, 3) Siswa dapat memilih dan menerapkan strategi pemecahan permasalahan sederhana, 4) Siswa dapat melakukan konseptulasi dan generalisasi dari sumber informasi yang berbeda, sehingga dibahas soal matematika berjenis PISA dalam penelitian ini.

Dalam penelitian ini dideskripsikan bagaimana kesadaran dan pengaturan berpikir siswa dalam menyelesaikan masalah pada soal PISA, terutama pada siswa yang mempunyai kemampuan tinggi dan rendah. Sebab, pada keduanya dapat diketahui bagaimana kesadaran dan pengaturan berpikir siswa yang berkemampuan tinggi dan siswa yang berkemampuan rendah, serta dapat diketahui sudahkah siswa yang berkemampuan tinggi dan siswa berkemampuan rendah telah melakukan atau menerapkan seluruh indikator kesadaran dan pengaturan berpikir dalam menyelesaikan masalah pada soal PISA, dan apakah siswa berkemampuan tinggi dan siswa yang berkemampuan rendah telah linear dalam menyusun langkah-langkah penyelesaian dalam memecahkan masalah pada soal PISA.

\section{METODE}

Penelitian ini termasuk ke dalam jenis penelitian kualitatif dengan menggunakan pendekatan deskriptif kualitatif. Pada penelitian ini fokus kepada analisis kesadaran dan pengaruh berpikir siswa dalam menyelesaikan soal-soal matematika yang bertipe PISA. Sehingga digambarkan serta dipaparkan hasil dari pengerjaan siswa dalam menyelesaikan soal matematika bertipe PISA baik dari proses pengerjaannya, konteks serta levelnya melalui tes juga wawancara kepada beberapa responden.

Penelitian dilakukan dari bulan April sampai Agustus 2020. Subjek pada penelitian ini adalah siswa kelas XI SMA Nurul Islam Jember, dengan menggunakan teknik purposive sampling dalam pengambilan subjek. Dalam teknik ini pengambilan subjek dilakukan dengan pertimbangan tertentu dengan nilai ulangan matematika yang paling baik di antara kelas lainnya. Kemudian dipilih 2 siswa untuk menjadi subjek penelitian yaitu 1 siswa untuk kategori siswa yang memiliki nilai paling tinggi dan 1 siswa untuk kategori siswa yang memiliki nilai paling rendah.

Penelitian ini menggunakan triangulasi waktu. Dimana triangulasi waktu ini dapat digunakan lebih dari satu kali mengumpulkan data untuk mencari hasil yang sama. Pada penelitian ini digunakan metode tes dan wawancara untuk mengumpulkan hasil kemampuan siswa dalam menyelesaikan masalah pada soal PISA. Data yang tidak dapat ditemukan pada hasil pengerjaan tes bisa didapatkan melalui data hasil wawancara.

Triangulasi waktu ini membutuhkan 2 subjek dimana pada penelitian ini diambil 1 siswa pada setiap katagori tingkat nilai ulangan harian matematika siswa. 1 siswa dengan nilai tinggi dan 1 siswa siswa dengan nilai rendah. Masing-masing siswa mengerjakan soal yang sama sekaligus menyuarakan hasil pemikirannya (think aloud) kemudian setelah mengerjakan soal tes akan dilanjutkan dengan tanya jawab. 
Hasil pengerjaan 2 siswa tersebut akan dianalisis apakah kesadaran dan pengaturan berpikir siswa nilai tinggi akan sama dengan siswa dengan nilai rendah.

Indikator kesadaran dan pengaturan berpikir siswa dalam menyelesaikan masalah pada soal PISA, serta struktur kesadaran dan pengaturan berpikir siswa mengacu pada indikator-indikator dari Baidawi (2017).

Berikut merupakan penyesuaian indikator kesadaran dan pengaturan siswa dengan teknik pengambilan data:

Tabel 1. Penyesuaian indikator kesadaran dan pengaturan berpikir siswa dengan teknik pengambilan data

\begin{tabular}{|c|c|c|c|c|c|}
\hline $\begin{array}{l}\text { Langkah } \\
\text { penyelesaian } \\
\text { masalah }\end{array}$ & Komponen & $\begin{array}{c}\text { Sub } \\
\text { komponen }\end{array}$ & Indikator & Deskripsi & $\begin{array}{c}\text { Teknik } \\
\text { pengambilan } \\
\text { data }\end{array}$ \\
\hline \multirow{5}{*}{$\begin{array}{l}\text { Menyajikan } \\
\text { masalah }\end{array}$} & \multirow[b]{2}{*}{$\begin{array}{l}\text { Kesadaran } \\
\text { berpikir }\end{array}$} & Attention & $\begin{array}{l}\text { Membaca soal } \\
\text { dengan seksama }\end{array}$ & $\begin{array}{l}\text { Sebelum menyajikan } \\
\text { masalah siswa membaca } \\
\text { soal dengan seksama }\end{array}$ & Wawancara \\
\hline & & $\begin{array}{l}\text { Recall Of } \\
\text { knowledge }\end{array}$ & $\begin{array}{l}\text { Mengetahui ide } \\
\text { atau gejala- } \\
\text { gejala yang } \\
\text { terdapat pada } \\
\text { soal }\end{array}$ & $\begin{array}{l}\text { Sebelum menyajikan } \\
\text { masalah, siswa harus } \\
\text { mengetahui ide atau } \\
\text { gejala-gejala pada soal }\end{array}$ & Wawancara \\
\hline & \multirow{3}{*}{$\begin{array}{l}\text { Pengaturan } \\
\text { berpikir }\end{array}$} & Planning & $\begin{array}{l}\text { Menganalisis } \\
\text { masalah yang } \\
\text { terdapat pada } \\
\text { soal }\end{array}$ & $\begin{array}{l}\text { Sebelum menyajikan } \\
\text { masalah, siswa harus } \\
\text { menganalisis masalah } \\
\text { pada soal }\end{array}$ & Tes \\
\hline & & Monitoring & $\begin{array}{l}\text { Mengukur } \\
\text { kesesuaian } \\
\text { langkah untuk } \\
\text { menganalisis } \\
\text { masalah }\end{array}$ & $\begin{array}{l}\text { Sebelum menyajikan } \\
\text { masalah, siswa harus } \\
\text { mengukur apakah } \\
\text { langkah menganalisis } \\
\text { masalah pada soal sudah } \\
\text { benar atau tidak }\end{array}$ & Tes \\
\hline & & Evaluation & $\begin{array}{l}\text { Mengidentifikas } \\
\text { masalah yang } \\
\text { terdapat pada } \\
\text { soal } \\
\end{array}$ & $\begin{array}{l}\text { Sebelum menyajikan } \\
\text { masalah, siswa harus } \\
\text { mengidentifikasi } \\
\text { masalah pada soal }\end{array}$ & Tes \\
\hline \multirow{4}{*}{$\begin{array}{l}\text { Mencari } \\
\text { penyelesaian }\end{array}$} & \multirow[b]{2}{*}{$\begin{array}{l}\text { Kesadaran } \\
\text { berpikir }\end{array}$} & Attention & $\begin{array}{l}\text { Membaca soal } \\
\text { secara } \\
\text { berulang-ulang }\end{array}$ & $\begin{array}{l}\text { Pada saat mencari } \\
\text { penyelesaian, siswa } \\
\text { membaca soal secara } \\
\text { berulang-ulang }\end{array}$ & Wawancara \\
\hline & & $\begin{array}{l}\text { Recall Of } \\
\text { knowledge }\end{array}$ & $\begin{array}{l}\text { Mengingat } \\
\text { kembali rumus } \\
\text { yang berkaitan } \\
\text { dengan soal }\end{array}$ & $\begin{array}{l}\text { Pada saat mencari } \\
\text { penyelesaian, siswa } \\
\text { mengingat kembali } \\
\text { rumus yang tepat } \\
\text { digunakan untuk } \\
\text { menyelesaikan masalah } \\
\text { pada soal }\end{array}$ & Wawancara \\
\hline & \multirow[t]{2}{*}{$\begin{array}{l}\text { Pengaturan } \\
\text { berpikir }\end{array}$} & Planning & $\begin{array}{l}\text { Menetapkan } \\
\text { rumus sesuai } \\
\text { kebutuhan soal }\end{array}$ & $\begin{array}{l}\text { Pada saat mencari } \\
\text { penyelesaian, siswa } \\
\text { menetapkan rumus } \\
\text { sesuai kebutuhan soal } \\
\end{array}$ & Tes \\
\hline & & Monitoring & $\begin{array}{l}\text { Mengukur } \\
\text { kesesuaian }\end{array}$ & $\begin{array}{l}\text { Pada saat mencari } \\
\text { penyelesaian, siswa }\end{array}$ & Tes \\
\hline
\end{tabular}




\begin{tabular}{|c|c|c|c|c|c|}
\hline & & & $\begin{array}{l}\text { penetapan } \\
\text { rumus }\end{array}$ & $\begin{array}{l}\text { mengukur apakah } \\
\text { penetapan rumus telah } \\
\text { sesuai dengan kebutuhan } \\
\text { soal atau tidak }\end{array}$ & \\
\hline & & Evaluation & $\begin{array}{l}\text { Mengidentifikasi } \\
\text { kesulitan yang } \\
\text { terdapat pada } \\
\text { rumus }\end{array}$ & $\begin{array}{l}\text { Pada saat mencari } \\
\text { penyelesaian, siswa } \\
\text { mengidentifikasi } \\
\text { kesulitan yang terdapat } \\
\text { pada rumus }\end{array}$ & Tes \\
\hline \multirow{5}{*}{$\begin{array}{l}\text { Menerapkan } \\
\text { penyelesaian }\end{array}$} & \multirow[t]{2}{*}{$\begin{array}{l}\text { Kesadaran } \\
\text { berpikir }\end{array}$} & Attention & $\begin{array}{l}\text { Berinteraksi } \\
\text { dengan soal } \\
\text { secara langsung }\end{array}$ & $\begin{array}{l}\text { Pada saat menerapkan } \\
\text { penyelesaian, siswa } \\
\text { menunjuk soal dengan } \\
\text { tangan misal untuk } \\
\text { memperhatikan angka } \\
\text { atau gambar pada soal } \\
\text { dengan lebih detil }\end{array}$ & Wawancara \\
\hline & & $\begin{array}{l}\text { Recall of } \\
\text { knowledge }\end{array}$ & $\begin{array}{l}\text { Mengingat } \\
\text { penggunaan } \\
\text { rumus dengan } \\
\text { baik }\end{array}$ & $\begin{array}{l}\text { Pada saat menerapkan } \\
\text { penyelesaian, siswa } \\
\text { harus mengingat } \\
\text { penggunaan rumus } \\
\text { dengan baik }\end{array}$ & Wawancara \\
\hline & \multirow{3}{*}{$\begin{array}{l}\text { Pengaturan } \\
\text { berpikir }\end{array}$} & Planning & $\begin{array}{l}\text { Menerapkan } \\
\text { angka pada } \\
\text { rumus }\end{array}$ & $\begin{array}{l}\text { Pada saat menerapkan } \\
\text { penyelesaian, siswa } \\
\text { menerapkan angka yang } \\
\text { telah diketahui pada soal } \\
\text { terhadap rumus yang } \\
\text { telah dipilih }\end{array}$ & Tes \\
\hline & & Monitoring & $\begin{array}{l}\text { Mengukur } \\
\text { kesesuaian } \\
\text { penerapan } \\
\text { angka pada } \\
\text { rumus }\end{array}$ & $\begin{array}{l}\text { Pada saat menerapkan } \\
\text { penyelesaian, siswa } \\
\text { mengukur sudah } \\
\text { sesuaikah penempatan } \\
\text { angka-angka yang telah } \\
\text { diketahui terhadap } \\
\text { rumus }\end{array}$ & Tes \\
\hline & & Evaluation & $\begin{array}{l}\text { Mengetahui } \\
\text { kemampuan } \\
\text { pemahaman diri } \\
\text { terhadap soal }\end{array}$ & $\begin{array}{l}\text { Pada saat menerapkan } \\
\text { penyelesaian, siswa } \\
\text { dapat mengidentifikasi } \\
\text { kesalahan pada hitungan } \\
\text { atau jawaban akhir dan } \\
\text { mengetahui kemampuan } \\
\text { pemahaman dirinya } \\
\text { sendiri dalam } \\
\text { menyelesaikan } \\
\text { permasalahan pada soal }\end{array}$ & Tes \\
\hline
\end{tabular}

\section{HASIL DAN PEMBAHASAN}

Berdasarkan aturan penggunaan soal PISA ditujukan khusus untuk anak berusia 15 tahun, yaitu usia anak pada kelas IX SMP hingga kelas X SMA, sehingga subjek pada penelitian ini menggunakan anak yang berada di bangku SMA yaitu kelas X IPA 1. Kelas X IPA 1 merupakan kelas yang siswanya mayoritas berumur 15 tahun. Kemudian ditentukan 2 siswa yang dijadikan sebagai subjek penelitian yang terdiri dari 1 siswa mendapat nilai tertinggi dan 1 siswa yang mendapat nilai 
terendah. Penentuan subjek ini dilakukan setelah dilakukan analisis pada nilai ulangan siswa di kelas X IPA 1.

Berdasarkan nilai ulangan harian, dapat diketahui terdapat dua siswa yang mendapat nilai tinggi dengan nilai 90 yang terdiri dari 1 siswa perempuan dan 1 siswa laki-laki. Sedangkan nilai terendah terdapat 1 siswa dan siswa tersebut berjenis kelamin perempuan dengan nilai 60. Sehingga pada penelitian ini, dipilih 1 siswa perempuan dengan nilai tinggi dan 1 siswa perempuan dengan nilai rendah. Tidak dipilih siswa laki-laki dengan nilai tertinggi karena Mubeen, Saeed, dan Arif (Susilowati, 2016) menjelaskan bahwa dalam mencapai prestasi matematika antara anak laki-laki dan anak perempuan sangatlah berbeda, hasil yang diperoleh anak perempuan cenderung lebih baik daripada anak laki-laki. Zhu (Susilowati, 2016) mengatakan bahwa perbedaan gender, pengalaman dan pendidikan merupakan faktor perbedaan pemecahan masalah dalam matematika. Oleh sebab itu, dipilih 2 subjek penelitian yang keduanya berjenis kelamin perempuan. S1 pengkodean untuk siswa berkemampuan tinggi dan S2 pengkodean untuk siswa berkemampuan rendah.

Berikut adalah hasil penelitian kesadaran dan pengaturan berpikir siswa dalam menyelesaikan masalah pada soal PISA untuk siswa berkemampuan tinggi yang diperoleh dari hasil pengerjaan soal tes dan wawancara:

Tabel 2. Deskripsi kesadaran dan pengaturan berpikir S1 think aloud dan wawancara dalam menyelesaikan masalah

\begin{tabular}{|c|c|c|c|c|c|}
\hline Kode & Think aloud & Deskripsi & Komponen & $\begin{array}{c}\text { Langkah } \\
\text { menyelesaikan } \\
\text { masalah } \\
\text { menurut Gick }\end{array}$ & $\begin{array}{c}\text { Teknik } \\
\text { pengambilan } \\
\text { data }\end{array}$ \\
\hline A & $\begin{array}{l}\text { Sebelum mengerjakan } \\
\text { soal, subjek membaca } \\
\text { soal dengan perlahan }\end{array}$ & $\begin{array}{l}\text { Pemusatan pikiran } \\
\text { dengan membaca } \\
\text { soal secara } \\
\text { seksama }\end{array}$ & 1) Attention & $\begin{array}{l}\text { Menyajikan } \\
\text { masalah }\end{array}$ & Wawancara \\
\hline B & $\begin{array}{l}\text { Subjek menulis apa saja } \\
\text { yang diketahui pada } \\
\text { soal } \\
\text { Diket: } \\
\mathrm{V}_{\text {turun }}=36 \mathrm{~km} / \mathrm{jam} \\
\mathrm{V}_{\text {naik }}=18 \mathrm{~km} / \mathrm{jam} \\
\mathrm{Kpp}=75 \mathrm{menit}\end{array}$ & $\begin{array}{l}\text { Menuliskan gejala- } \\
\text { gejala yang } \\
\text { diketahui pada soal }\end{array}$ & $\begin{array}{l}\text { 2) Recall of } \\
\text { knowledge }\end{array}$ & $\begin{array}{l}\text { Menyajikan } \\
\text { masalah }\end{array}$ & Tes \\
\hline C & $\begin{array}{l}\text { Subjek menulis } \\
\text { permasalahan pada soal } \\
\text { Ditanya: } \mathrm{t}=\ldots \text { ? }\end{array}$ & $\begin{array}{l}\text { Menuliskan } \\
\text { permasalahan pada } \\
\text { soal }\end{array}$ & 3) Planning & $\begin{array}{l}\text { Menyajikan } \\
\text { masalah }\end{array}$ & Tes \\
\hline $\mathrm{H}$ & $\begin{array}{l}\text { Subjek menulis rumus } \\
\begin{aligned} \mathrm{t}_{\text {pergi }} & =\frac{75}{2} \\
& =37,5 \mathrm{~m}\end{aligned} \\
\mathrm{~s}=\mathrm{v} \cdot \mathrm{t}\end{array}$ & $\begin{array}{l}\text { Menentukan rumus } \\
\text { yang tepat } \\
\text { digunakan untuk } \\
\text { menyelesaikan } \\
\text { masalah pada soal }\end{array}$ & 4) Planning & $\begin{array}{l}\text { Mencari } \\
\text { penyelesaian }\end{array}$ & Tes \\
\hline M & $\begin{array}{l}\text { Subjek menulis } \\
\text { pengerjaannya } \\
\mathrm{s}=\frac{37,5}{2.60} \cdot 36 \cdot \frac{5}{18}+\frac{37,5}{2.60} . \\
18 \cdot \frac{5}{18}\end{array}$ & $\begin{array}{l}\text { Menerapkan angka } \\
\text { yang diketahui } \\
\text { pada soal ke dalam } \\
\text { rumus }\end{array}$ & 5) Planning & $\begin{array}{l}\text { Menerapkan } \\
\text { penyelesaian }\end{array}$ & Tes \\
\hline
\end{tabular}




\begin{tabular}{|c|c|c|c|c|c|}
\hline & $\begin{array}{l}\mathrm{s}=\frac{37,5}{12}+\frac{37,5}{24} \\
\mathrm{~s}=\frac{75+37,5}{24} \\
\mathrm{~s}=\frac{112,5}{24} \\
\mathrm{~s}=46,8 \mathrm{~km}\end{array}$ & & & & \\
\hline $\mathrm{N}$ & $\begin{array}{l}\text { "Looh, iya ding ini } \\
\text { salah, soalnya kan tak } \\
\text { jadikan km/jam } \\
\text { harusnya kan ngga usah } \\
\text { dikali } \frac{5}{18} \text {, kalau } \\
\text { dikalikan } \frac{5}{18} \text { kan } \\
\text { jadikan meter/sekon. } \\
\text { Tak kerjakan lagi ya?" }\end{array}$ & $\begin{array}{l}\text { Sedang menilai } \\
\text { apakah pekerjaan } \\
\text { dirinya sendiri } \\
\text { telah benar atau } \\
\text { tidak }\end{array}$ & 6) Monitoring & $\begin{array}{l}\text { Menerapkan } \\
\text { penyelesaian }\end{array}$ & Wawancara \\
\hline $\mathrm{O}$ & $\begin{array}{l}\text { Subjek nampak terjeda- } \\
\text { jeda ketika menuliskan } \\
\text { jawaban kembali }\end{array}$ & $\begin{array}{l}\text { Mengalami } \\
\text { kesulitan saat } \\
\text { menyelesaikan } \\
\text { masalah pada soal }\end{array}$ & 7) Evaluation & $\begin{array}{l}\text { Menerapkan } \\
\text { penyelesaian }\end{array}$ & Tes \\
\hline $\mathrm{f}, \mathrm{k}$ & $\begin{array}{l}\text { Nampak subjek } \\
\text { membaca soal kembali } \\
\text { sambil menunjuk soal } \\
\text { dengan tangan }\end{array}$ & $\begin{array}{l}\text { Membaca soal } \\
\text { berulang dan } \\
\text { berinteraksi dengan } \\
\text { soal secara } \\
\text { langsung } \\
\text { menggunakan } \\
\text { tangan }\end{array}$ & 8) Attention & $\begin{array}{l}\text { Mencari } \\
\text { penyelesaian }\end{array}$ & Tes \\
\hline $\mathrm{D}$ & $\begin{array}{l}\text { Subjek membaca soal } \\
\text { berulang untuk } \\
\text { memahami } \\
\text { permasalahan pada soal }\end{array}$ & $\begin{array}{l}\text { Mengukur apakah } \\
\text { permasalahan yang } \\
\text { diketahui pada soal } \\
\text { sudah benar atau } \\
\text { tidak }\end{array}$ & 9) Monitoring & $\begin{array}{l}\text { Menyajikan } \\
\text { masalah }\end{array}$ & Tes \\
\hline G & $\begin{array}{l}\text { Setelah membaca soal } \\
\text { subjek terdiam sejenak } \\
\text { saat ditanya "Apakah } \\
\text { sudah dapat rumus } \\
\text { yang tepat? } \\
\text { "Iya sudah" jawab } \\
\text { subjek }\end{array}$ & $\begin{array}{l}\text { Mengingat kembali } \\
\text { rumus yang } \\
\text { digunakan untuk } \\
\text { menyelesaikan } \\
\text { masalah pada soal }\end{array}$ & $\begin{array}{l}\text { 10) Recall of } \\
\text { knowledge }\end{array}$ & $\begin{array}{l}\text { Mencari } \\
\text { penyelesaian }\end{array}$ & Wawancara \\
\hline $\mathrm{H}$ & $\begin{array}{l}\text { Subjek kembali } \\
\text { menuliskan } \\
\mathrm{s}=\mathrm{v} \cdot \mathrm{t}\end{array}$ & $\begin{array}{l}\text { Menentukan rumus } \\
\text { yang tepat untuk } \\
\text { menyelesaikan } \\
\text { masalah pada soal }\end{array}$ & 11)Planning & $\begin{array}{l}\text { Mencari } \\
\text { penyelesaian }\end{array}$ & Tes \\
\hline $\mathrm{I}$ & $\begin{array}{l}\text { Subjek terdiam sejenak, } \\
\text { lalu ditanya "Sudah } \\
\text { benar ini rumusnya?" } \\
\text { Subjek menjawab "Iya" }\end{array}$ & $\begin{array}{l}\text { Mengukur apakah } \\
\text { rumus yang telah } \\
\text { ditetapkan sudah } \\
\text { benar atau tidak }\end{array}$ & 12)Monitoring & $\begin{array}{l}\text { Mencari } \\
\text { penyelesaian }\end{array}$ & Wawancara \\
\hline $\mathrm{L}$ & $\begin{array}{l}\text { Subjek mengatakan } \\
\text { telah ingat dengan } \\
\text { penggunaan soal } \\
\text { dengan baik saat } \\
\text { ditanya "ingatkah } \\
\text { subjek dengan } \\
\text { penggunaan rumus } \\
\text { yang telah ditetapkan?" }\end{array}$ & $\begin{array}{l}\text { Mengingat } \\
\text { penggunaan rumus }\end{array}$ & $\begin{array}{l}\text { 13) Recall of } \\
\text { knowledge }\end{array}$ & $\begin{array}{l}\text { Menerapkan } \\
\text { penyelesaian }\end{array}$ & Wawancara \\
\hline M & Subjek menulis & Menerapkan angka & 14)Planning & Menerapkan & Tes \\
\hline
\end{tabular}




\begin{tabular}{|c|c|c|c|c|c|}
\hline & $\begin{array}{l}\mathrm{s}=\frac{37,5}{2 \cdot 60} \cdot 36 \cdot+\frac{37,5}{2 \cdot 60} \cdot 18 \\
\mathrm{~s}=\frac{112,5}{10}+\frac{37,5}{10} \\
\mathrm{~s}=11,25+3,75 \\
\mathrm{~s}=15 \mathrm{~km}\end{array}$ & $\begin{array}{l}\text { yang diketahui } \\
\text { pada soal ke dalam } \\
\text { rumus yang telah } \\
\text { ditetapkan }\end{array}$ & & penyelesaian & \\
\hline $\mathrm{N}$ & $\begin{array}{l}\text { "Nah kalau gini bener } \\
\text { kak, hasilnya bukan } \\
\text { koma-koma, jadi bulat } \\
\text { angkanya" }\end{array}$ & $\begin{array}{l}\text { Mengukur apakah } \\
\text { penerapan angka } \\
\text { pada rumus sudah } \\
\text { benar atau tidak }\end{array}$ & 15)Monitoring & $\begin{array}{l}\text { Menerapkan } \\
\text { penyelesaian }\end{array}$ & Wawancara \\
\hline $\mathrm{O}$ & $\begin{array}{l}\text { Subjek menuliskan } \\
\therefore \text { Jarak rumah Faris ke } \\
\text { sekolah adalah } 15 \mathrm{~km}\end{array}$ & $\begin{array}{l}\text { Membuat } \\
\text { kesimpulan dari } \\
\text { hasil pengerjaannya }\end{array}$ & 16)Evaluation & $\begin{array}{l}\text { Menerapkan } \\
\text { penyelesaian }\end{array}$ & Tes \\
\hline
\end{tabular}

Berdasarkan tabel di atas dapat digambarkan suatu struktur penyelesaian serta struktur kesadaran dan pengaturan berpikir S1 dalam menyelesaikan masalah sesuai pada penelitian Baidawi (2017) yang dimodifikasi warna garis penghubung langkah satu dengan langkah berikutnya.

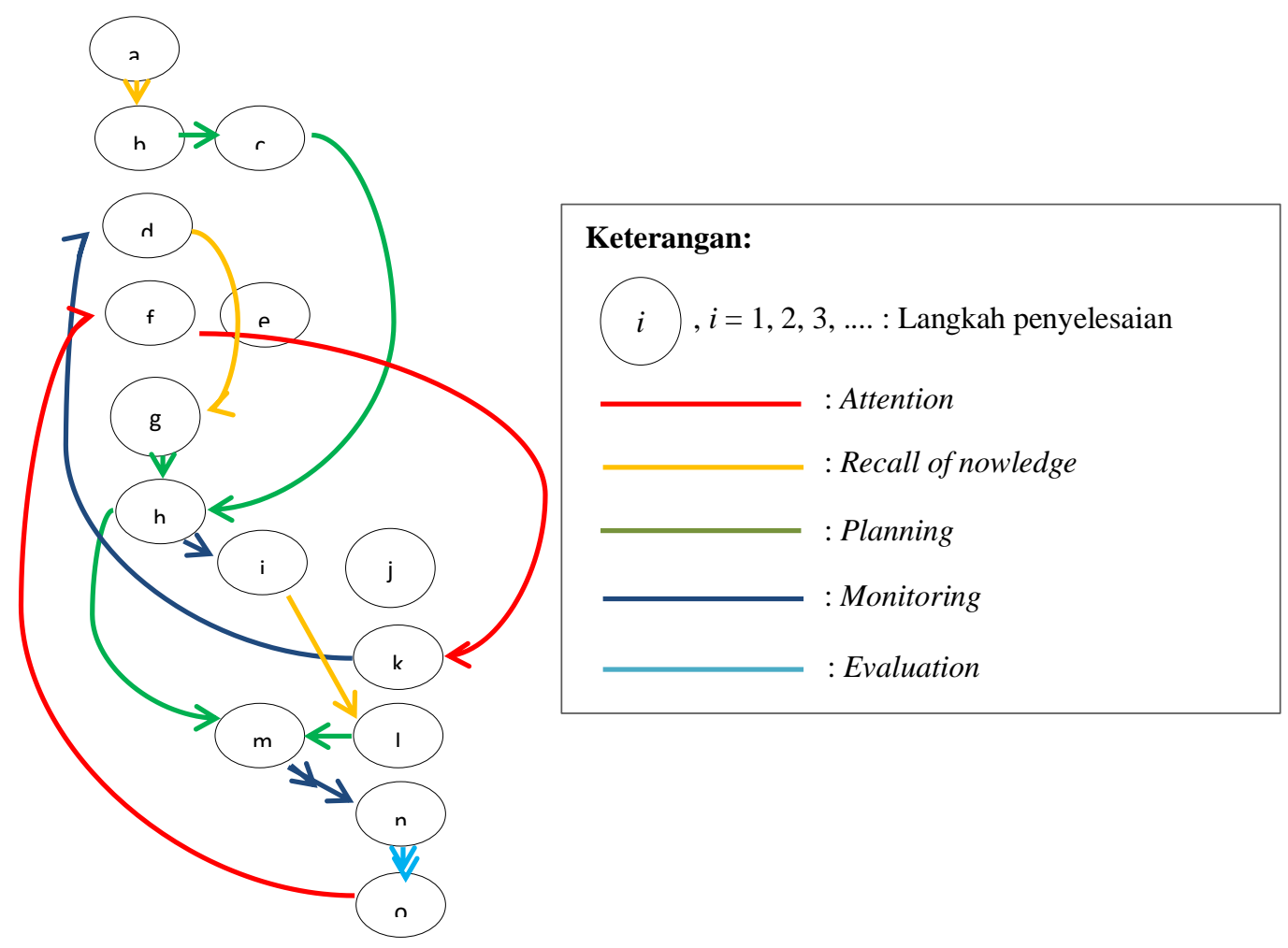

Gambar 1. Struktur penyelesaian masalah S1

Berdasarkan gambar di atas bahwa proses kesadaran dan pengaturan berpikir S1 bergerak dengan tidak linear, yang artinya tidak berurutan dan berulang-ulang. Pada soal tes ini S1 bergerak dari attention, recall of knowledge, planning, planning, monitoring, evaluation, attention, attention, monitoring, recall of knowledge, planning, monitoring, recall of knowledge, planning, monitoring kemudian evaluation. 
Kesadaran dan pengaturan berpikir subjek dengan nilai tinggi dalam menyelesaikan masalah pada soal PISA materi kecepatan saat fase attention subjek membaca soal dengan seksama. Fase tersebut digunakan subjek menuju fase selanjutnya yaitu fase recall of knowledge, subjek mencari gejala yang terdapat pada soal, termasuk apa saja yang diketahui serta permasalahan pada soal. Setelah itu subjek memasuki fase planning merencanakan dan menetapkan rumus untuk menyelesaikan permasalahan pada soal. Saat subjek merasa hasil dari pengerjaannya salah, subjek segera mencoret jawaban tersebut dan mulai membaca kembali soal secara berulang-ulang untuk memahami permasalahan pada soal dengan benar. Kemudian subjek mengingat kembali penggunaan rumus yang telah ditetapkan, lalu subjek menerapkan angka ke dalam rumus sesuai dengan kebutuhan permasalahan pada soal. Setelah subjek merasa jawabannya benar, subjek menambahkan kesimpulan pada hasil akhir pengerjaannya. Pengerjaan subjek termasuk berdurasi panjang, sebab subjek sangat meneliti permasalahan yang terdapat pada soal. Subjek termasuk siswa yang berpikir logis. Pemikiran subjek telah sampai pada titik tersebut. Sehingga subjek akan memeriksa kembali jawaban yang telah ada menjadi jawaban yang logis.

Berikut merupakan hasil penelitian kesadaran dan pengaturan berpikir siswa berkemampuan rendah dalam menyelesaikan masalah pada soal PISA:

Tabel 3. Deskripsi kesadaran dan pengaturan berpikir S2 berdasarkan think aloud dan wawancara dalam menyelesaikan masalah

\begin{tabular}{|c|c|c|c|c|c|}
\hline Kode & Think aloud & Deskripsi & Komponen & $\begin{array}{c}\text { Langkah } \\
\text { menyelesaikan } \\
\text { masalah menurut } \\
\text { Gick }\end{array}$ & $\begin{array}{c}\text { Teknik } \\
\text { pengambilan } \\
\text { data }\end{array}$ \\
\hline A & $\begin{array}{l}\text { Sebelum subjek } \\
\text { mengerjakan soal, } \\
\text { subjek membaca } \\
\text { soal dengan } \\
\text { perlahan }\end{array}$ & $\begin{array}{l}\text { Memusatkan pikiran } \\
\text { dengan membaca } \\
\text { soal secara seksama }\end{array}$ & 1) Attention & $\begin{array}{l}\text { Menyajikan } \\
\text { masalah }\end{array}$ & Wawancara \\
\hline B & $\begin{array}{l}\text { Subjek menulis apa } \\
\text { saja yang diketahui } \\
\text { pada soal } \\
\text { Diket: } \\
\mathrm{t}=75 \text { menit pulang } \\
\text { pergi }\end{array}$ & $\begin{array}{l}\text { Menuliskan gejala- } \\
\text { gejala yang } \\
\text { diketahui pada soal }\end{array}$ & $\begin{array}{l}\text { 2) Recall of } \\
\text { knowledge }\end{array}$ & $\begin{array}{l}\text { Menyajikan } \\
\text { masalah }\end{array}$ & Wawancara \\
\hline & $\begin{array}{l}\mathrm{v}_{\mathrm{t}}=36 \mathrm{~km} / \mathrm{jam} \\
\mathrm{v}_{\mathrm{m}}=18 \mathrm{~km} / \mathrm{jam}\end{array}$ & & & & \\
\hline $\mathrm{C}$ & $\begin{array}{l}\text { Subjek menulis } \\
\text { permasalahan pada } \\
\text { soal } \\
\text { Ditanya: jarak (s) }\end{array}$ & $\begin{array}{l}\text { Menuliskan } \\
\text { permasalahan pada } \\
\text { soal }\end{array}$ & 3) Planning & $\begin{array}{l}\text { Menyajikan } \\
\text { masalah }\end{array}$ & Tes \\
\hline G & $\begin{array}{l}\text { Ketika ditanya: } \\
\text { "Udah kepikiran } \\
\text { sama rumus buat cari } \\
\text { yang ditanyakan } \\
\text { ini?" } \\
\text { Subjek menjawab: } \\
\text { "Iya kak" }\end{array}$ & $\begin{array}{l}\text { Mengingat kembali } \\
\text { rumus yang tepat } \\
\text { digunakan untuk } \\
\text { menyelesaikan } \\
\text { permasalahan pada } \\
\text { soal }\end{array}$ & $\begin{array}{l}\text { 4) Recall of } \\
\text { knowledge }\end{array}$ & $\begin{array}{l}\text { Mencari } \\
\text { penyelesaian }\end{array}$ & Wawancara \\
\hline
\end{tabular}




\begin{tabular}{|c|c|c|c|c|c|}
\hline $\mathrm{H}$ & $\begin{array}{l}\text { Subjek menulis } \\
\text { rumus } \\
\mathrm{s}=\frac{v}{t}\end{array}$ & $\begin{array}{l}\text { Menentukan rumus } \\
\text { yang tepat } \\
\text { digunakan untuk } \\
\text { menyelesaikan } \\
\text { permasalahan pada } \\
\text { soal }\end{array}$ & 5) Planning & $\begin{array}{l}\text { Mencari } \\
\text { penyelesaian }\end{array}$ & Tes \\
\hline $\mathrm{m}$ & $\begin{array}{l}\text { Subjek menulis } \\
\text { pengerjaannya } \\
\mathrm{s}=\frac{v}{t} \\
\mathrm{~s}=\frac{36+18}{37,5} \\
\mathrm{~s}=\frac{54}{37,5}\end{array}$ & $\begin{array}{l}\text { Menerapkan angka } \\
\text { yang diketahui pada } \\
\text { soal ke dalam rumus }\end{array}$ & 6) Planning & $\begin{array}{l}\text { Menerapkan } \\
\text { penyelesaian }\end{array}$ & Tes \\
\hline $\mathrm{N}$ & $\begin{array}{l}\text { Kemudian subjek } \\
\text { mencoret jawaban }\end{array}$ & $\begin{array}{l}\text { Subjek merasa } \\
\text { pengerjaannya salah }\end{array}$ & 7) Monitoring & $\begin{array}{l}\text { Menerapkan } \\
\text { penyelesaian }\end{array}$ & Tes \\
\hline $\mathrm{f}, \mathrm{k}$ & $\begin{array}{l}\text { (membaca soal lagi } \\
\text { secara berulang dan } \\
\text { menunjuk soal } \\
\text { dengan bolpoin) }\end{array}$ & $\begin{array}{l}\text { Membaca soal } \\
\text { secara berulang dan } \\
\text { menunjuk soal } \\
\text { menggunakan } \\
\text { tangan secara } \\
\text { langsung }\end{array}$ & 8) Attention & $\begin{array}{l}\text { Menyajikan } \\
\text { masalah }\end{array}$ & Wawancara \\
\hline M & $\begin{array}{l}\text { Kemudian subjek } \\
\text { menulis } \\
\mathrm{s}=\frac{v}{t} \\
\mathrm{~s}=\frac{36+18}{75} \\
\mathrm{~s}=\frac{54}{75} \\
\mathrm{~s}=0,72: 2 \\
\mathrm{~s}=0,36\end{array}$ & $\begin{array}{l}\text { Menerapkan angka } \\
\text { yang diketahui pada } \\
\text { soal ke dalam rumus }\end{array}$ & 9) Planning & $\begin{array}{l}\text { Menerapkan } \\
\text { penyelesaian }\end{array}$ & Tes \\
\hline $\mathrm{n}$ & $\begin{array}{l}\text { (mengangguk) } \\
\text { Sambil berkata } \\
\text { "Sudah ya kak" } \\
\text { kemudian berdiri }\end{array}$ & $\begin{array}{l}\text { Subjek merasa } \\
\text { jawabannya tidak } \\
\text { perlu dibenarkan lagi } \\
\text { dan ingin mengakhiri } \\
\text { soal tes ke-2 }\end{array}$ & 10)Monitoring & $\begin{array}{l}\text { Menerapkan } \\
\text { penyelesaian }\end{array}$ & Wawancara \\
\hline
\end{tabular}

Berdasarkan tabel di atas dapat digambarkan suatu struktur penyelesaian serta struktur kesadaran dan pengaturan berpikir S2 dalam menyelesaikan masalah sesuai pada penelitian Baidawi (2017) yang dimodifikasi warna garis penghubung langkah satu dengan langkah berikutnya. 

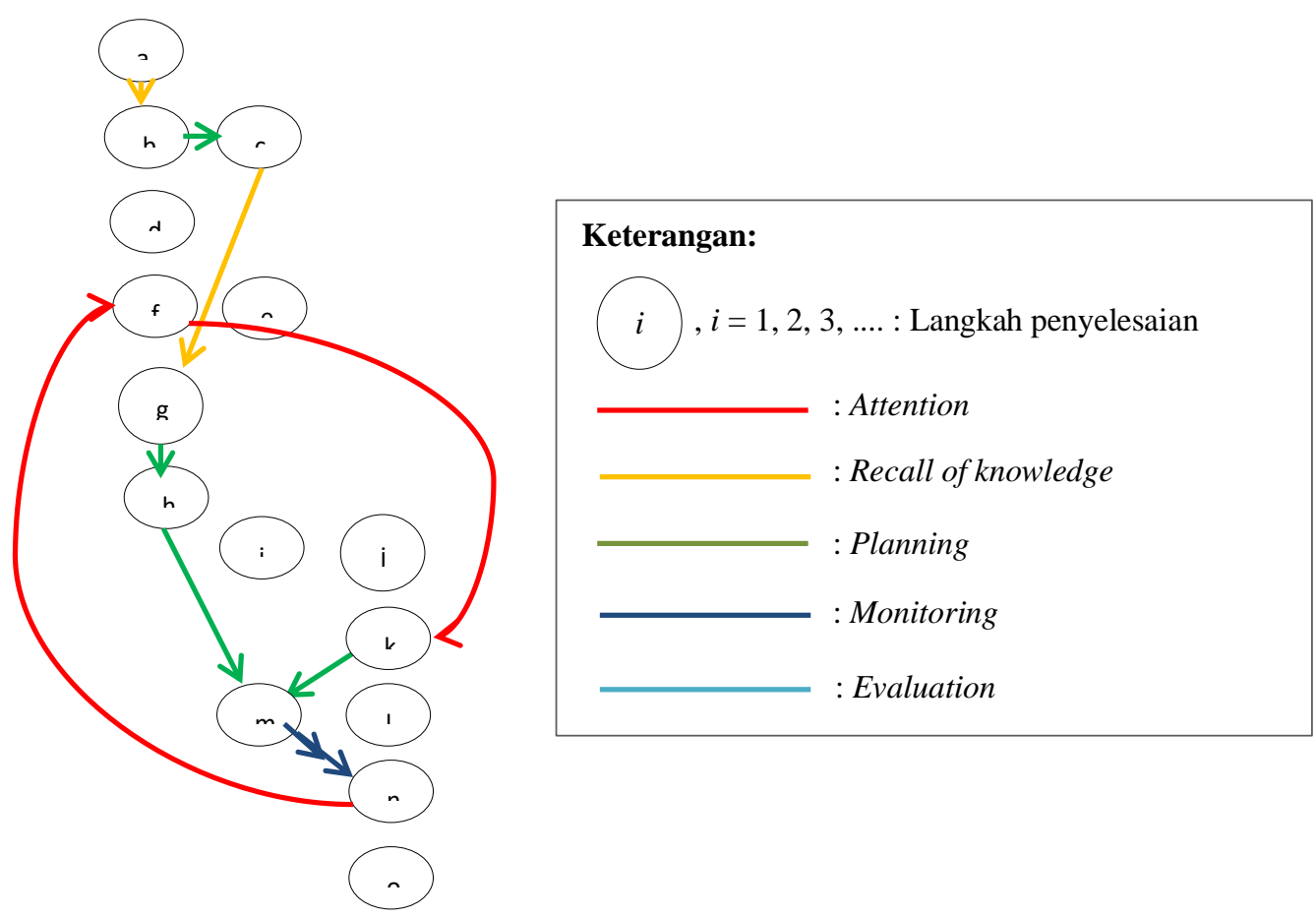

Gambar 2. Struktur penyelesaian masalah S2

Berdasarkan gambar di atas bahwa proses kesadaran dan pengaturan berpikir S2 bergerak dengan tidak linear, yang artinya tidak berurutan dan berulang-ulang. Pada soal tes ini S2 bergerak dari attention, recall of knowledge, planning, recall of knowledge, planning, planning, attention, attention planning, monitoring, kemudian kembali pada attention. Sehingga, dapat diperoleh keterkaitan struktur kesadaran dan pengaturan berpikir dengan struktur penyelesaian masalah.

Kesadaran dan pengaturan berpikir subjek dengan nilai rendah dalam menyelesaikan soal PISA materi kecepatan dimulai pada fase attention subjek membaca soal dengan perlahan dan seksama untuk menghindari kesalahan dalam membaca ataupun meneliti permasalahan pada soal. Namun subjek tidak selalu menggunakan fase recall of knowledge dengan baik pada soal tes yang diberikan. Pada setiap kesempatan yang diberikan, subjek selalu tidak mengingat terhadap rumus yang seharusnya subjek pikirkan dan digunakan untuk menyelesaikan permasalahan pada soal. Selain itu subjek tidak mengetahui gejala apa saja yang dapat diketahui pada soal dengan benar. Sehingga hal ini berpengaruh pada fase planning, subjek tidak dapat merencanakan rumus yang tepat untuk menyelesaikan permasalahan pada soal serta subjek tidak dapat me-monitoring dirinya sendiri, hal tersebut akan berpengaruh pada fase evaluation, subjek tidak memberikan kesimpulan dari hasil pengerjaannya. Pengerjaan subjek termasuk berdurasi pendek, saat pengamatan dilakukan, subjek terlihat sangat putus asa ketika tidak dapat memahami permasalahan yang terdapat pada soal. Selain itu subjek juga tidak memonitoring serta meng-evaluation hasil dari pengerjaannya. Sehingga waktu yang subjek gunakan untuk menyelesaikan permasalahan pada soal cenderung cepat. Bahkan subjek terburu-buru untuk mengakhiri tes yang diberikan, tanpa memeriksa kembali hasil dari pengerjaannya tersebut benar ataupun salah. 
Gambar 6 dan gambar 7 berikut ini merupakan struktur keterkaitan kesadaran dan pengaturan berpikir dengan struktur penyelesaian masalah S1 dan S2:

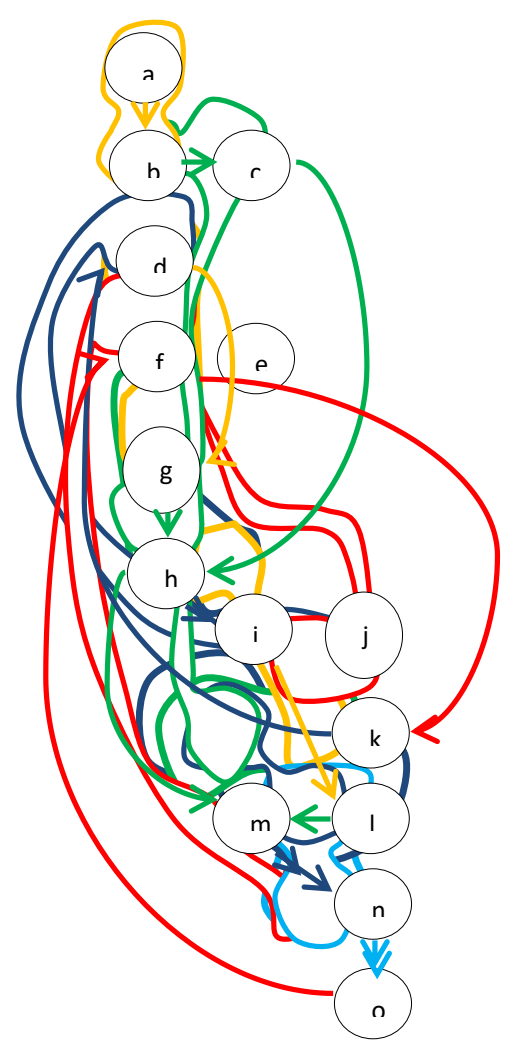

\section{Keterangan:}

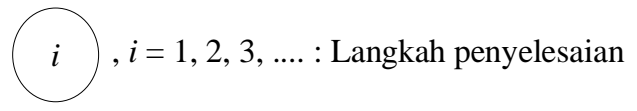

: Attention

: Recall of Knowledge

: Planning

: Monitoring

: Evaluation

Gambar 3. Keterkaitan struktur kesadaran dan pengaturan berpikir dengan struktur penyelesaian masalah S1
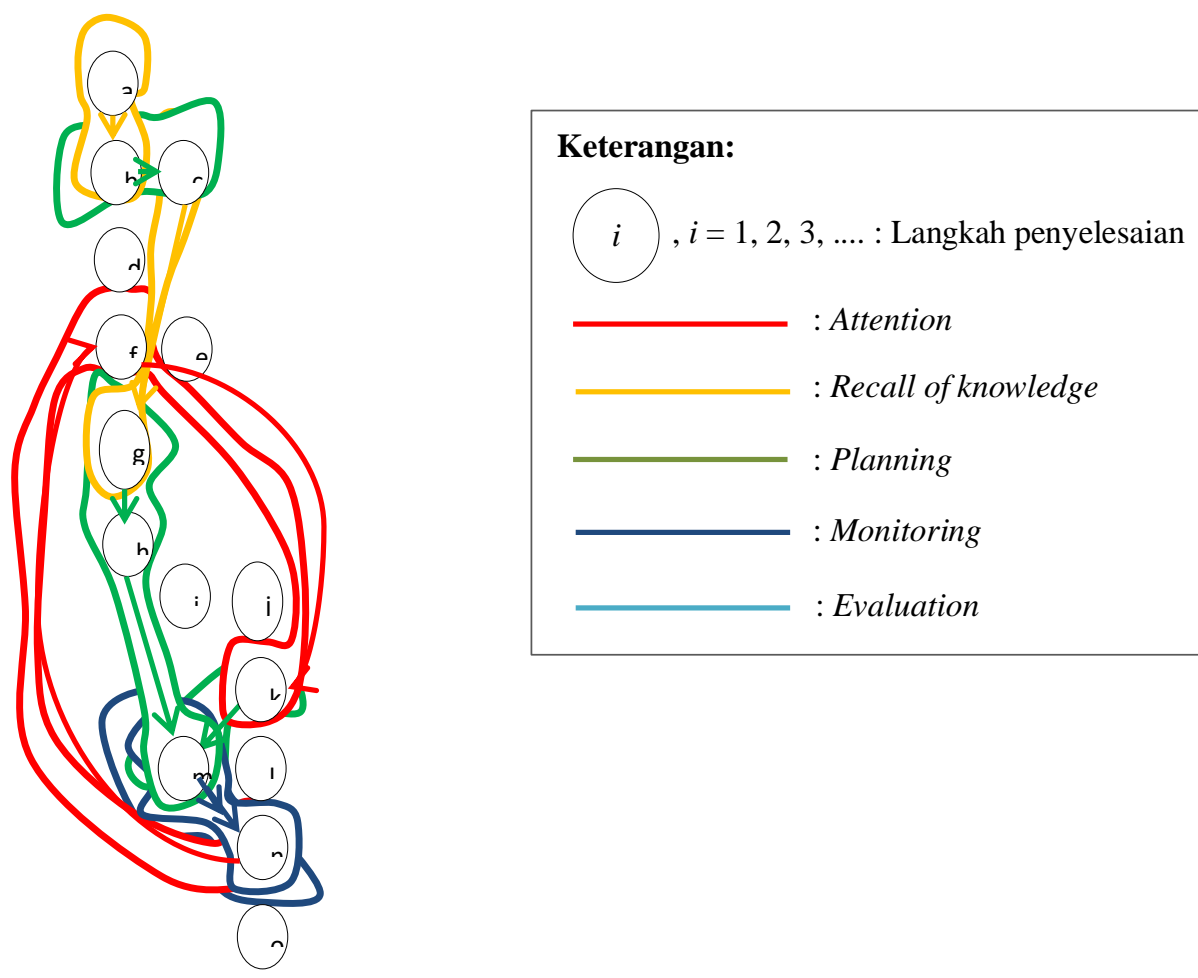

Gambar 4. Keterkaitan struktur kesadaran dan pengaturan berpikir dengan struktur penyelesaian masalah $\mathrm{S} 2$ 
Dari keseluruhan hasil pengerjaan tertulis subjek, struktur kesadaran dan pengaturan berpikir siswa mempunyai pola tertentu. Yang pertama yaitu struktur penyelesaian masalah lengkap, kemudian struktur kesadaran dan pengaturan berpikir juga lengkap, sehingga struktur kesadaran dan pengaturan berpikir siswa dalam menyelesaikan masalah dinyatakan lengkap. Struktur kesadaran dan pengaturan berpikir lengkap jika komponen dari penyelesaian masalahnya lengkap yaitu komponen dengan kode kegiatan a, b,c, d, f, g, h, i, j, k, l, m, n dan o telah dilakukan. Sedangkan komponen kesadaran dan pengaturan berpikir lengkap yaitu attention, recall of knowledge, planning, monitoring, dan evaluation telah dilakukan. Yang kedua yaitu struktur penyelesaian tidak lengkap dan struktur kesadaran dan pengaturan berpikir juga tidak lengkap, sehingga struktur kesadaran dan pengaturan berpikir siswa dalam menyelesaikan masalah dinyatakan tidak lengkap. Struktur kesadaran dan pengaturan berpikir serta struktur penyelesaian masalah tidak lengkap jika tidak memenuhi seluruh komponen dari struktur kesadaran dan pengaturan berpikir serta struktur penyelesaian masalah. Proses bergeraknya kesadaran dan pengaturan berpikir siswa tidak linear, artinya adalah bergerak tidak secara berurutan dan berulang-ulang. Sesuai dengan Kuzzle (Baidawi, 2017) bahwa proses metakognitif bergerak tidak linear, namun siklis, dinamis dan berulang, yaitu bergerak dari komponen satu pada komponen lainnya kemudian kembali pada komponen semula.

\section{SIMPULAN DAN SARAN}

Berdasarkan hasil penelitian dari 2 subjek tersebut, diperoleh bahwa kesadaran dan pengaturan berpikir siswa berkemampuan tinggi dan siswa berkemampuan rendah berbeda serta bergerak secara tidak linear. Siswa berkemampuan tinggi dalam menyelesaikan masalah pada materi kecepatan yaitu melalui komponen attention, recall of knowledge, planning, planning, monitoring, evaluation, attention, attention, monitoring, recall of knowledge, planning, monitoring, recall of knowledge, planning, monitoring kemudian evaluation. Sedangkan kesadaran dan pengaturan berpikiran siswa berkemampuan rendah dalam menyelesaikan masalah pada materi kecepatan yaitu melalui komponen attention, recall of knowledge, planning, planning, monitoring, evaluation, attention, attention, monitoring, recall of knowledge, planning, monitoring, recall of knowledge, planning, monitoring kemudian evaluation.

Komponen kesadaran dan pengaturan berpikir dalam penelitian ini masih terbatas pada attention, recall of knowledge, planning, monitoring dan evaluation. Untuk penelitian selanjutnya dapat ditambahkan komponen-komponen baru, serta dapat memfokuskan pada proses transisi dari kesadaran ke pengaturan berpikir atau dari komponen kesadaran ke komponen pengaturan berpikir.

\section{DAFTAR PUSTAKA}

Baidawi, M. 2017. Kesadaran dan Pengaturan Berpikir Guru Prospektif dalam Menyelesaikan Masalah Aljabar. Disertasi tidak diterbitkan. Malang: Universitas Negeri Malang. 
Brigham, J. C. 1991. Social Psychology. 2nd Edition. New York: HarperCollins Publishers, cop.

Dhany, A. 2013. PISA (Programme Internationale for Student Assesment). [Online]. Tersedia: https://dhanymatika.wordpress.com/2013/09/02/pisa-programmeinternationale-for-student-assesment/. [6 April 2020].

Schraw, G. and Moshman, D. 1995. Metacognitive Theories. Educational Psychology Papers and Publications. Paper $40: 351-371$.

Solso, R. dkk. 2008. Psikologi Kognitif. Edisi Delapan. Jakarta: Erlangga.

Suherman, E. dkk. 2001. Strategi Pembelajaran Matematika Kontemporer. Bandung: JICA-Universitas Pendidikan Indonesia.

Sulisawati, D.N. 2013. Pengaturan Diri Siswa SMP dengan Gaya Kognitif Reflektif dan Impulsif dalam Menyelesaikan Masalah Aljabar. Tesis tidak diterbitkan. Surabaya : Universitas Negeri Surabaya.

Susilowati, J.P.A. 2016. Profil Penalaran Siswa SMP dalam Pemecahan Masalah Matematika Ditinjau dari Perbedaan Gender. JRPM (Jurnal Review Pembelajaran Matematika), Vol. 1(2) : 132-148.

Wardhani, S. dan Rumiati. 2011. Instrumen Penilaian Hasil Belajar Matematika SMP: Belajar dari PISA dan TIMSS. Yogyakarta: KemenDikNas dan PPPPTK.

Widjajanti, D. B. 2009. Kemampuan Pemecahan Masalah Matematis Mahasiswa Calon Guru Matematika: Apa dan Bagaimana Mengembangkannya. Makalah Pada Prosiding Seminar Nasional Matematika dan Pendidikan Matematika Jurusan Pendidikan Matematika FMIPA Universitas Negeri Yogyakarta, Yogyakarta, 5 Desember 2009. Hal: 402-413. ISSN 978-979-16353-3-2.

Zayyadi, M. dan Sulfiah, K. 2018. Analisis Literasi Matematika Siswa Berkemampuan Matematika Tinggi Pada Soal PISA. [Online]. Tersedia: https://www.academia.edu/38286917/ANALISIS_LITERASI_MATEMATIK A_SISWA_BERKEMAMPUAN_MATEMATIKA_TINGGI_PADA_SOAL_ PISA.pdf. [20 Mei 2020]. 